\title{
Initiation of Fetal Rat Lung Phospholipid and Surfactant-Associated Protein A mRNA Synthesis
}

\author{
IAN GROSS, CHRISTINE M. WILSON, JOANNA FLOROS, AND DIANE W. DYNIA \\ Division of Perinatal Medicine, Department of Pediatrics, Yale University School of Medicine, New Haven, CT \\ 06510 [I.G., C.M.W., D.W.D.] and Department of Pediatrics, Harvard Medical School, Boston, MA 02215 [J.F.]
}

\begin{abstract}
To determine whether the initiation of fetal lung surfactant phospholipid production and the activation of the gene for the $35-\mathrm{kD}$ surfactant-associated protein are dependent on circulating corticosteroids, we cultured dexamethasone-responsive explants of 15- to 17-d fetal rat lung in medium with $1 \%$ FCS (controls), charcoal-stripped $1 \%$ FCS, or a variety of glucocorticoid antagonists. The steroid antagonist RU 486 almost completely abolished specific cytoplasmic and nuclear dexamethasone binding in the explants but had no glucocorticoid-agonist activity. There was a significant increase in disaturated phosphatidylcholine synthesis during $7 \mathrm{~d}$ in culture in control explants $(\mathbf{7 8} \%)$ and in those cultured with Charcoal-stripped serum $(83 \%)$, RU $486(82 \%)$, or the other glucocorticoid antagonists-clotrimazole, cortexelone, and 11-ketoprogesterone. Specific mRNA for surfactant-associated protein $A$ was not detectable in preculture 17-d lung tissue, but accumulated to the same extent in cultures with or without RU 486 in the medium. These findings support the view that expression of the genes responsible for the synthesis of the various components of surfactant is not induced by glucocorticoids, but by signals contained within the lung tissue itself. The role of circulating hormones is later acceleration and modulation of surfactant production. (Pediatr Res 25:239-244, 1989)
\end{abstract}

\section{Abbreviation}

SP-A, surfactant-associated protein A

Although it is clear that fetal lung development is accelerated by a number of hormones, it has not been established that circulating hormones are responsible for inducing expression of the genes responsible for surfactant synthesis (1). In the rat, mouse, and sheep, but not the rabbit, free plasma corticosteroid levels have been reported to rise at about the same time that the surge in surfactant production occurs (2). Studies with organ cultures from a variety of species have indicated that the biochemical and anatomical maturation of the fetal lung begins and continues in culture in the absence of added hormones $(1,3-$ 10 ), whereas studies with isolated cells have suggested that corticosteroids are necessary for biochemical development in culture $(11,12)$.

We have previously shown that explants of $14-$ through 20 -d

Received August 8, 1988; accepted October 26, 1988.

Correspondence Ian Gross, M.D., Department of Pediatrics, Yale University School of Medicine, P.O. Box 3333, New Haven, CT 06510.

Supported by NIH Grants HL 19752, HL 34788, and HL 38288. fetal rat lung will develop in culture in the presence of medium containing $1 \%$ FCS or no serum at all (1). In the case of the later gestation (18-20 d) explants, it is possible that as the tissue had already been exposed to hormones in vivo, maturation was stimulated before the lung tissue was cultured. The earlier gestation (14-15 d) explants were cultured in the presence of $1 \%$ FCS that contained trace amounts of hormones, including 0.5 $\mathrm{nM}$ cortisol. It is possible that these small amounts of hormones were adequate to initiate lung maturation, that the lung tissue already contained active hormones, or that it converted inactive hormones to their active forms. In contrast to the findings in explants, studies with monolayer cultures of mixed fetal lung cells have indicated that corticosteroids are necessary for promoting lung differentiation in culture and that in the absence of these hormones lung differentiation is arrested $(11,12)$.

In an attempt to resolve the issue of whether glucocorticoids are responsible for initiating surfactant synthesis, we have cultured explants of $15-$ to $17-\mathrm{d}$ fetal rat lung medium in which the serum was treated with charcoal to remove low-mol-wt substances or to which various glucocorticoid antagonists, including the potent steroid receptor antagonist RU 486 [11 $\beta$-(4-dimethyl aminophenyl) $17 \beta$-hydroxy, $17 \alpha$-(prop-1 ynyl) estra 4,9-dien-3one], were added. RU 486 is a synthetic steroid with a high binding affinity for progesterone and glucocorticoid receptors (13). It has previously been shown to have no agonist activity, but to have strong antiglucocorticoid effects in vivo and in vitro $(13,14)$. We examined the effects of glucocorticoid receptor blockade on phospholipid synthesis and the appearance of mRNA for the 35-kD SP-A.

\section{MATERIALS AND METHODS}

Tissue culture. All experiments were performed with explants of 15 - or 17 -d fetal rat lung, cultured for up to $7 \mathrm{~d}$. The culture technique has been described in detail previously $(1,15)$. The lungs were removed under sterile conditions and dissected free of connective tissue and large airways. The lungs were then separated into individual lobes and the lobes cut into small pieces (see Fig. 2B under "Results"). The explants were placed on either side of a 60 -mm-diameter tissue culture dish that contained 2 ml of Waymouth's MB 752/1 medium with $100 \mathrm{U}$ of penicillin, $100 \mathrm{mg}$ of streptomycin, and $3.0 \mu \mathrm{g}$ fungizone $/ \mathrm{ml}$ as well as various additions as are described below. Scratches were made on the culture dishes to promote adherence of the explants. The culture medium was changed every other day. The dishes were rocked from side to side on a rocking platform at about 3 cycles/ min so that at any one time half the explants were exposed to the culture medium and the other half to the humidified atmosphere of $95 \%$ air, $5 \% \mathrm{CO}_{2}$ in the case of 15 -d lung explants or $50 \% \mathrm{O}_{2}, 45 \% \mathrm{~N}_{2}$ and $5 \% \mathrm{CO}_{2}$ in the case of the 17-d explants. (Our previous studies have indicated that as fetal rat lung matures 
the requirement for oxygen by explant cultures increases; the concentrations used here were optimal for gestational age.)

Additions to culture medium. For the studies of morphologic development and phospholipid synthesis, explants of 15-d lung were used. Control cultures were grown in Waymouths's medium with $1 \%$ FCS. Aliquots of this serum were also charcoal treated by the method of Sato (16), and a group of explants was cultured in medium with $1 \%$ charcoal-stripped FCS. Other cultures were incubated in control medium with $0.1-$ to $10-\mu \mathrm{M}$ clotrimazole, 0.1 - to $10-\mu \mathrm{M}$ cortexolone (11-desoxy-17 hydroxycorticosterone), 10- to 1000-nM 11-ketoprogesterone, 20- to 200-nM RU 486 , or 50-nM dexamethasone. For the studies of mRNA accumulation, explants of 17-d lung were cultured in Waymouth's medium with $1 \%$ charcoal-stripped serum in the presence or absence of 100-nM RU 486.

Lipid synthesis. After varying periods in culture, the medium was aspirated and replaced with fresh medium containing 12 $\mu \mathrm{Ci} / \mathrm{mol}\left[\right.$ methyl- ${ }^{3} \mathrm{H}$ ]choline chloride, $2.23 \mathrm{Ci} / \mathrm{mol}$, or $26 \mu \mathrm{Ci} /$ $\left.\mathrm{ml} \mathrm{[}{ }^{3} \mathrm{H}\right] \mathrm{Na}$ acetate, $6.4 \mathrm{Ci} / \mathrm{mol}$. Incubation was continued for an additional $4 \mathrm{~h}$. The explants were then washed with ice-cold $0.9 \% \mathrm{NaCl}$, lipids were extracted, phospholipids were isolated by thin-layer chromatography, and the radioactivity in the various phospholipid fractions was determined by methods described previously (15). Protein content was measured by the method of Lowry et al. (17) using BSA as a standard.

Glucocorticoid binding. Binding of dexamethasone was assayed using intact cell techniques as described previously (18). After 24 $\mathrm{h}$ of preincubation in various concentrations of RU 486 or clotrimazole, $\left[{ }^{3} \mathrm{H}\right]$ dexamethasone, $35 \mathrm{nmol}$, was added to the explants, and incubation was continued for $3 \mathrm{~h}$ at $37^{\circ} \mathrm{C}$. An aliquot of the incubation medium was counted to determine the concentration of free dexamethasone. At the end of the incubation, the tissue was washed with ice-cold saline and homogenized in cold buffer. A nuclear and cytoplasmic fraction were prepared by centrifugation as described previously (3). To remove free dexamethasone, the cytoplasmic fraction was applied to a Sephadex G 25 column, and the void vol collected and retained. The nuclear fraction was washed twice, and radioactivity in both fractions was determined by liquid scintillation counting. Nonspecific binding, determined in the presence of a 500 -fold excess of dexamethasone, was subtracted from total binding to give specific binding.

$R N A$ extraction and Northern blotting. Explants were washed and harvested in cold sterile $0.9 \% \mathrm{NaCl}$ and hand homogenized in $4-\mathrm{M}$ guanidinium thiocyanate, $25-\mathrm{mM}$ sodium citrate, $\mathrm{pH}$ $7.0,0.5 \%$ sodium $N$-lauroyl sarcosinate and $0.1-\mathrm{M} \beta$-mercaptoethanol $(19,20)$. DNA was sheared by aspiration several times through a 22 -gauge needle.

A total of $2.5 \mathrm{ml}$ of homogenate was layered onto an equal vol of 5.7-M cesium chloride, 0.1-M EDTA, pH 7.0, and centrifuged at $100,000 \times g$ for $20 \mathrm{~h}$. The pellet was rinsed with $70 \%$ ethanol, suspended in 0.1-M Tris EDTA, pH 7.0, and then precipitated with $0.1-\mathrm{M}$ sodium acetate and $100 \%$ ethanol and centrifuged for $15 \mathrm{~min}$ at $15,000 \times \mathrm{g}$. This procedure was repeated three times. The pellet was then suspended in water. The amount of RNA was determined by the OD at $260 \mathrm{~nm}$. Explants from the same experiment were processed simultaneously.

Next, 20 or $40 \mu \mathrm{g}$ of total RNA in buffer were loaded into each well of a $1 \%$ agarose $6.3 \%$ formaldehyde gel. After electrophoresis, the gels were stained with ethidium bromide, and the RNA bands were visualized under UV light. RNA was then transferred to Genescreen filters according to the recommendations of the vendor (New England Nuclear, Boston, MA). The Genescreen filter was washed, dried, and baked at $80^{\circ} \mathrm{C}$ for $4 \mathrm{~h}$.

Rat lung SP-A CDNA probe. The Genescreen filters were hybridized with a rat lung SP-A cDNA probe which will be described in more detail elsewhere (J. Floros, D.S. Phelps, H.P. Harding, S. Church, J. Ware, in preparation). To isolate the cDNA clone, a rat lung cDNA library was screened with a human
SP-A cDNA probe (21). The positive clones were further characterized by hybrid selection. The selected mRNA was translated in an in vitro translation system, and the translation products from the selected RNA were identical to the rat SP-A primary translation products when rat lung RNA was used (22). In addition, the translation products from the selected RNA are immunoprecipitable with an antiserum to human SP-A (20, 22, 23) and antiserum to rat SP-A. The positive rat cDNA clone recognizes the two different-sized SP-A mRNA described by Sano et al (24).

Hybridization assay. The SP-A cDNA was labeled with [ $\alpha-$ $\left.{ }^{32} \mathrm{P}\right] \mathrm{dCTP}(3000 \mathrm{Ci} / \mathrm{mmol})$ using a nick translation kit obtained from Amersham Corp. (Arlington Heights, IL). The probe was labeled to a sp act of $10^{7}-10^{8} \mathrm{cpm} / \mu \mathrm{g}$. The Genescreen filters were prehybridized overnight at $42^{\circ} \mathrm{C}$ and then hybridized to the $\left[{ }^{33} \mathrm{P}\right] \mathrm{dCTP}$-labeled SP-A cDNA probe $\left(2-3 \times 10^{5} \mathrm{cpm} / \mathrm{ml}\right.$ of hybridization solution) for $2-3 \mathrm{~d}$ at $42^{\circ} \mathrm{C}$. The conditions and buffers used for hybridization and washing of the filters were as described by the vendor (Biotechnology Systems, New England Nuclear Research Products. Feb. 1987). The filters were then exposed to XAR Kodak film (Eastman Kodak Co., Rochester, $\mathrm{NY}$ ) with an intensifying screen at $-70^{\circ} \mathrm{C}$ for a few $\mathrm{d}$. The density of the specific RNA bands on the autoradiograms was quantified by a laser densitometer (Biomed Instruments, Fullerton, CA).

Materials. [Methyl- $\left.{ }^{3} \mathrm{H}\right]$ choline chloride and $\left[1,2,4-{ }^{3} \mathrm{H}\right] \mathrm{dexa}-$ methasone were purchased from Amersham. RU 486 was a gift from the Centre de Recherche Roussel Uclaf, Romainville, France. Guanidinium thiocyanate was purchased from American Bioanalytical Labs, Natick, MA; cesium chloride from GallardSchlesinger, Carle Place, NY; and agarose from Bio-Rad Laboratories, Rockville Centre, NY. Clotrimazole, 11-ketoprogesterone and other biochemicals and hormones were purchased from Sigma Chemical Co., St. Louis, MO. Cortexolone was purchased from Aldrich Chemical Company, Metuchen, NJ. Tissue culture dishes were obtained from Costar, Cambridge, MA.

\section{RESULTS}

RU $486(13,14)$ and clotrimazole $(25)$ have been shown to inhibit glucocorticoid binding in a variety of organs and cell lines, including rat liver and thymus and hepatoma cells. To determine whether these compounds inhibit glucocorticoid binding in fetal rat lung, explants were cultured in the presence of

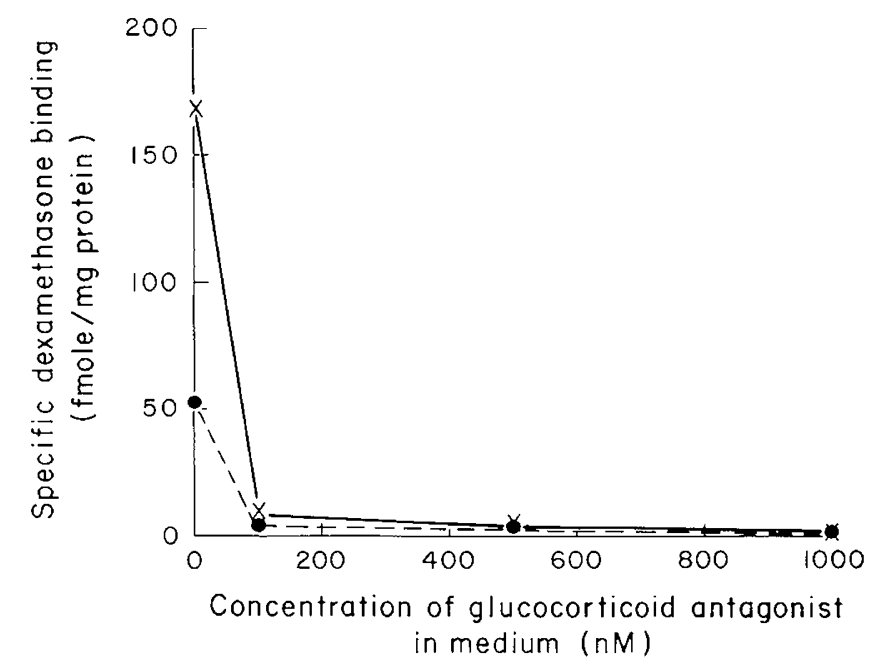

Fig. 1. Effect of RU 486 on specific glucocorticoid binding in explants of fetal rat lung. Explants were incubated in the presence of $35-n M\left[{ }^{3} \mathrm{H}\right]$ dexamethasone and varying concentrations of RU 486 for $3 \mathrm{~h}$. Solid line, specific nuclear dexamethasone binding; broken line, specific cytoplasmic dexamethasone binding. (Data represent the mean of two experiments. In each experiment, all values were derived from triplicate culture dishes.) 
0.1 - to $10-\mu \mathrm{M}$ clotrimazole or $100-, 500-$, or 1000 -nM RU 486 for $24 \mathrm{~h}$. After this preincubation, specific dexamethasone binding was determined under conditions that had previously been shown to be optimal. Clotrimazole had no effect on glucocorticoid binding. As is shown in Figure 1, RU 486 markedly antagonized both cytoplasmic and nuclear dexamethasone binding. At a concentration of 100-nM RU 486 (and 35-nM $\left[{ }^{3} \mathrm{H}\right]$ dexamethasone), specific glucocorticoid binding was reduced to less than $10 \%$ of the control value, and there was a further reduction with increasing concentrations of the antagonist. To determine whether RU 486 also had an agonist effect, explants of 18-d fetal rat lung were cultured in the presence of 20 - to 200-nM RU 486 for $48 \mathrm{~h}$ under conditions which had previously proven optimal for demonstrating dexamethasone stimulation in this system (26). There was no significant enhancement of choline incorporation into phosphatidylcholine with any of these concentrations of RU 486. In addition, when 17-d lung explants were incubated for $72 \mathrm{~h}$ with $50-\mathrm{nM}$ dexamethasone, the dexamethasone-induced $75 \%$ stimulation of choline incorporation was reduced to less than half if 100 -nM RU 486 was also added to the incubation medium. (Data not shown.)

The effects of incubation with control medium ( $1 \%$ serum) or RU 486 on the overall morphologic development of the lung explants are shown in Figures 2, 3, and 4. As is shown in Figure $2 A$, the lungs of the 15-d fetal rat consist of tubular epithelial tissue which has just begun to bud into the surrounding mesenchyme. An example of the pieces of lung which were used in the cultures is shown in Figure $2 \mathrm{~B}$. After $3 \mathrm{~d}$ in culture in control medium ( $1 \%$ serum), there was considerable budding of the respiratory tract (Fig. 3). By $5 \mathrm{~d}$, the budding had progressed further in the control cultures (Fig. $4 A$ ) and the mesenchymal tissue had become completely incorporated into the structure of
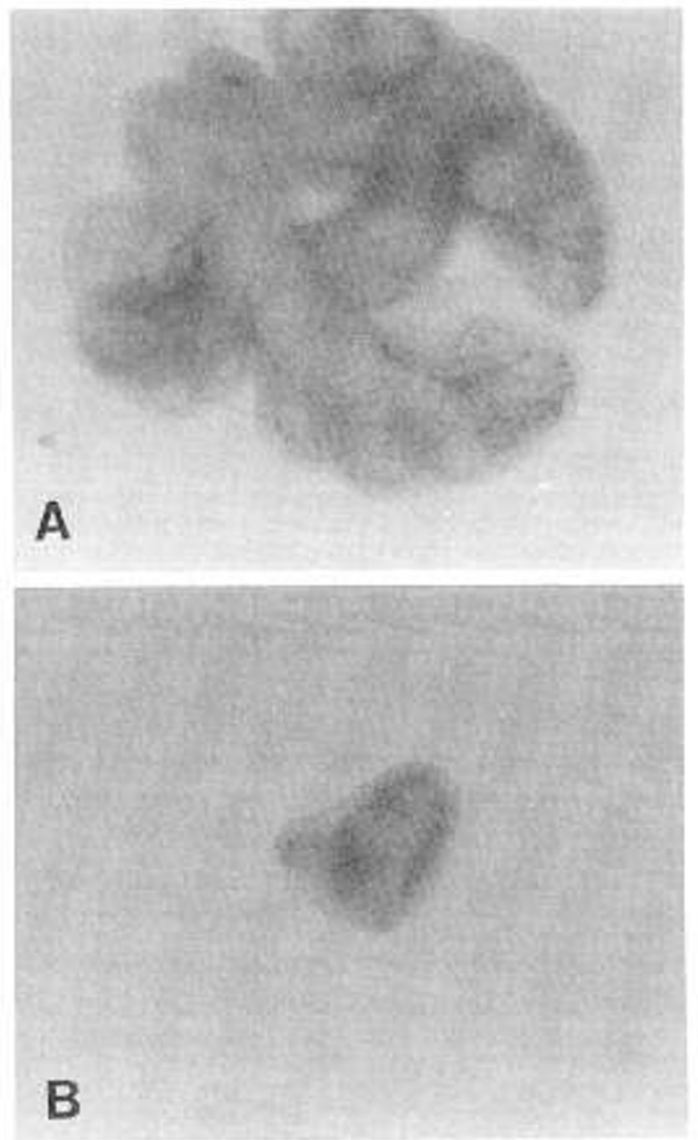

Fig. 2. $A$, a pair of 15-d fetal rat lungs; $B$, an example of the pieces of explanted lung used in this study, before culture. (Original magnification, $25 \times$.)

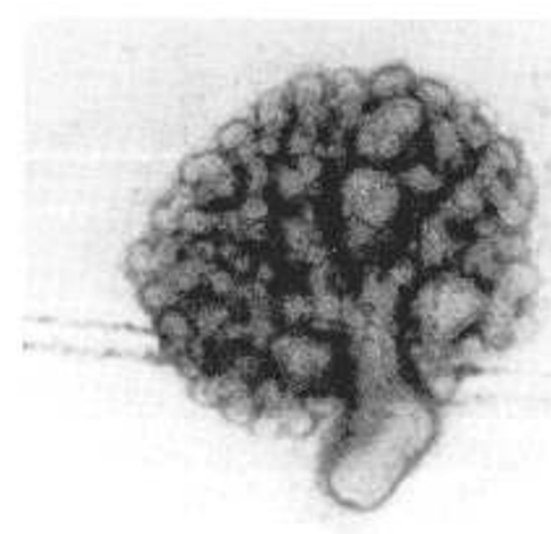

Fig. 3. Fetal rat lung explants (15-d) after $3 \mathrm{~d}$ in culture. The explant was cultured in Waymouths MB $752 / 1$ medium with $1 \%$ FCS. (Original magnification $25 \times$.)

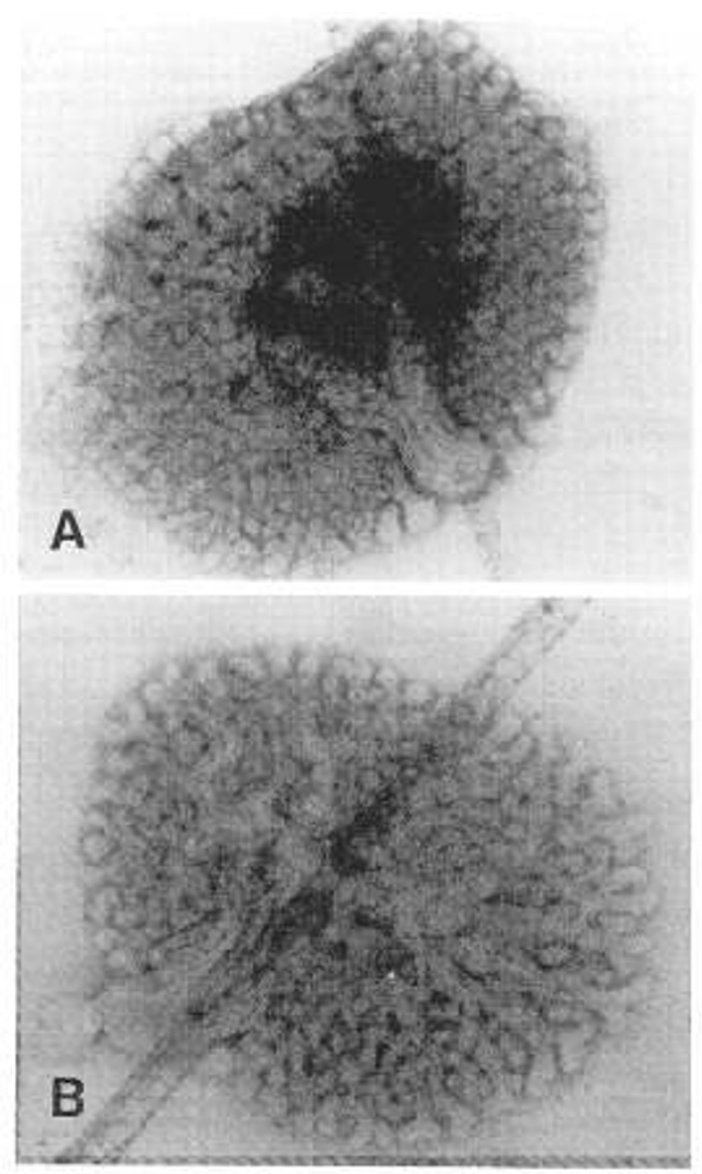

Fig. 4. Fetal rat lung explants (15-d) after $5 \mathrm{~d}$ in culture. $A$, cultured in medium with $1 \%$ FCS; $B$, cultured in medium with $1 \%$ FCS and 200 nM RU 486. (Original magnification $25 \times$.)

the lung. Culturing the explants in medium with RU 486 (Fig. 4 $B$ ) did not produce any obvious inhibition of this process. This observation was consistent in six experiments.

The rate of choline incorporation into disaturated phosphatidylcholine increased considerably over $7 \mathrm{~d}$ in culture. As Table 1 shows, there was a more than $75 \%$ increase in choline incorporation into disaturated phosphatidylcholine from d 3 to 7 when explants of 15 -d lung were cultured in the presence of $1 \%$ FCS, whether or not the serum had been charcoal treated. Addition of RU 486 to the culture medium did not inhibit choline incorporation into disaturated phosphatidylcholine in 
Table 1. Development of disaturated phosphatidylcholine synthesis in culture*

\begin{tabular}{|c|c|c|c|c|}
\hline & \multirow{3}{*}{$n$} & \multicolumn{3}{|c|}{$\begin{array}{l}\text { Choline incorporation into } \\
\text { disaturated phosphatidylcholine }\end{array}$} \\
\hline & & \multicolumn{2}{|c|}{$\mathrm{pmol} / \mathrm{h} / \mathrm{mg}$ protein } & \multirow{2}{*}{ Increase } \\
\hline & & $3 \mathrm{~d}$ & $7 \mathrm{~d}$ & \\
\hline $1 \% \mathrm{FCS}$ & 8 & $140 \pm 12$ & $249 \pm 24 \dagger$ & $78 \%$ \\
\hline $1 \%$ FCS - charcoal stripped & 4 & $132 \pm 16$ & $241 \pm 37 \dagger$ & $83 \%$ \\
\hline
\end{tabular}

* Explants of 15 -d lung were cultured for the number of $d$ indicated, as described in the text; data represent the mean \pm SEM.

$\dagger$ Statistically significant difference from $3-d$ value, $p<0.05$ by ANOVA with Student-Newman-Keuls test.

the cultures. As is shown in Table 2, the increase in incorporation for 3-7 d in culture was at least as great in those cultures that were exposed to RU 486 as in control cultures.

The percentage of phosphatidycholine that was disaturated was examined after incubation with $\left[{ }^{3} \mathrm{H}\right]$ acetate. This ratio was $38.9 \%$ after $2 \mathrm{~d}$ in culture and increased to $43.3 \%$ in control cultures and $45.1 \%$ in RU 486-treated cultures after $7 \mathrm{~d}$. After 2 $\mathrm{d}, 1.9 \%$ of the phospholipid radioactivity was found in the phosphatidylglycerol fraction. After $7 \mathrm{~d}$, the values were $1.8 \%$ in the controls and $3.0 \%$ in the RU 486-treated explants. None of these changes were statistically significant $(N=3)$.

Exposure of the explants for $7 \mathrm{~d}$ to clotrimazole, a putative glucocorticoid receptor antagonist (25), at concentrations of 0.1 , 1.0 and $10.0 \mu \mathrm{M}$; cortexolone, a glucocorticoid antagonist (27), at concentrations of $0.1,1.0$, and $10.0 \mu \mathrm{M}$; or 11-ketoprogesterone, an inhibitor of the conversion of dehydrocorticosterone to the more active form corticosterone (28), at concentrations of 10,100 , and $1000 \mathrm{nM}$ did not result in inhibition of choline incorporation as compared to control cultures. At the highest concentration of cortexolone, the explants did not grow well, and there was a considerable decrease in the amount of protein in these cultures.

Similar results were obtained when the influence of RU 486 on the accumulation of mRNA for SP-A was examined in explants of 17-d lung cultured for $5 \mathrm{~d}$. No mRNA was detectable in Northern blots of RNA extracted from preculture 17-d lung. After $5 \mathrm{~d}$ in culture in medium with $1 \%$ charcoal-stripped serum, specific mRNA was detectable and was not reduced by addition of RU 486, $100 \mathrm{nM}$, to the culture medium (Fig. 5). The mRNA bands were quantified by means of a laser densitometer, confirming the absence of an inhibitory effect of RU 486. The integrated area under the densitometer generated curve (in arbitrary units) was $28.5 \pm 3.7$ for the controls and $33.2 \pm 8.2$ for the RU 486treated cultures, $n=3$.

\section{DISCUSSION}

An unresolved issue in fetal lung development is whether the genes responsible for the synthesis of the many components of surfactant are activated by circulating hormones or by intrinsic pulmonary stimuli such as growth factors, products of the extracellular matrix, or cell-cell interactions. Although it is clear that hormones such as glucocorticoids and thyroid hormone accelerate fetal lung maturation in vivo and in vitro, it has not been established that these or other hormones are responsible for initiating surfactant production. The data that have been published thus far are somewhat contradictory. Some in vivo studies have shown that surfactant synthesis increases in lambs before the rise in cortisol levels; others have not (29-31). In the rat (32, 33) and mouse (34) plasma free corticosteroid levels rise at about the same time that surfactant production increases, but this is not the case in the rabbit (2). The assumption underlying these studies has been that a rise in hormone levels preceding or coinciding with the increase in surfactant production would
Table 2. Development of disaturated phosphatidylcholine synthesis in culture-influence of RU $486^{*}$

Choline incorporation into

disaturated phosphatidylcholine ( $\mathrm{pmol} / \mathrm{h} / \mathrm{mg}$ protein)

$\begin{array}{ll}3 \mathrm{~d} \text { in culture } & \\ \text { Control } & \\ 7 \mathrm{~d} \text { in culture } & \\ \text { Control } & 224 \pm 13 \dagger \\ \text { RU 486, 20 nM } & 253 \pm 15 \dagger \\ \text { RU 486, 50 nM } & 250 \pm 9 \dagger \\ \text { RU 486, 200 nM } & 290 \pm 25 \dagger\end{array}$

* Explants of 15-d lung were cultured for the times indicated in medium containing $1 \%$ FCS; data represent the mean \pm SEM of three experiments.

$\dagger$ Statistically significant difference from 3 -d control value, $p<0.05$, by ANOVA with Student-Newman-Keuls test. (There were no significant differences among the various groups cultured for $7 \mathrm{~d}$.)

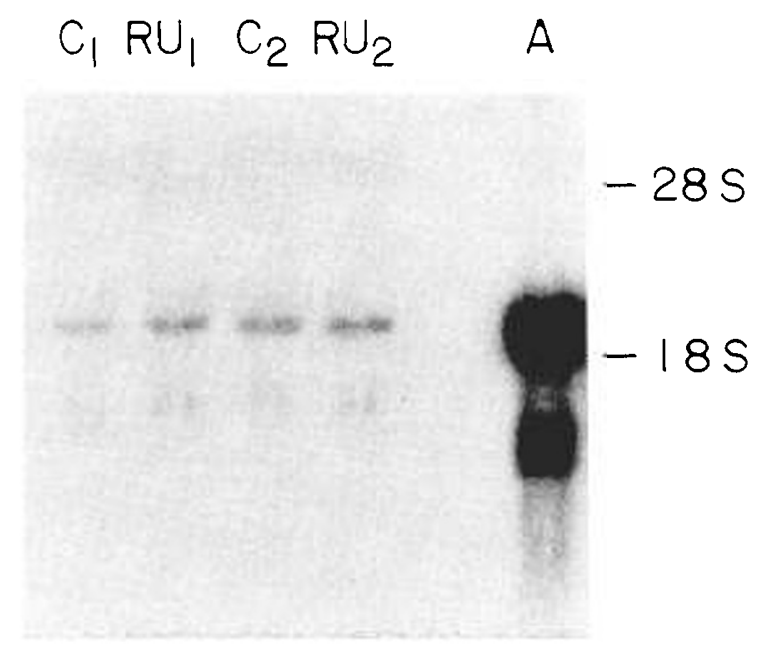

Fig. 5. Influence of RU 486 on the appearance of mRNA for SP-A in explant culture. Explants of 17-d fetal rat lung were cultured for $5 \mathrm{~d}$ in medium with charcoal-stripped $1 \% \mathrm{FCS}$, with or without 100-nM RU 486. mRNA for SP-A was determined by Northern blotting and hybridization with a $\left[{ }^{32} \mathrm{P}\right]$-labeled rat lung SP-A cDNA probe as described in "Materials and Methods." $C_{1}$, control culture, experiment $1 ; R U_{1}$, culture grown in the presence of RU486, experiment $1 ; A$, adult lung. This experiment was repeated three times, and mRNA content was quantified by laser densitometry as reported in "Results."

provide evidence for a causal relationship between the two events. A number of studies have also examined the effect of hypophysectomy or decapitation on fetal lung maturation. These studies have generally shown that under these conditions fetal lung maturation is considerably delayed, but not that it is necessarily stopped. For example, when the pituitary of fetal sheep of 99$122 \mathrm{~d}$ gestation was ablated, there was a resulting reduction in circulating cortisol and prolactin levels. Lung maturation in these animals was retarded so that at term the degree of maturity was comparable to that in 130-d fetuses $(29,35)$. Development of the lung did, however, continue at a slow rate in the absence of pituitary hormones.

Other researchers (3-9) and we ourselves $(1,10)$ have previously shown that fetal human, rat, and rabbit lung continues both biochemical and morphologic maturation [including the appearance of lamellar bodies in alveolar lining cells (10)] in organ or organotypic culture in systems in which the culture medium was kept constant and there could not have been any surge in hormone levels. Our experiments with fetal rat lung 
were conducted with either serum-free medium or medium containing $1 \%$ serum in which the level of hormones was measured, found to be low, and was well below the concentration that produces half maximal stimulation for phosphatidylcholine synthesis (1). We noted that development in culture occurred in a pattern similar to that seen in vivo, although in explants of early fetal lung it was not as rapid as that in vivo or in cultures of later gestation fetal lung. This may relate to the fact that in vivo and in the cultures of late gestation lung the tissue is or has been exposed to relatively high levels of circulating hormones. [Levels of corticosterone and thyroid hormones start to increase significantly about $4 \mathrm{~d}$ before term in the rat $(32,36)$.] It should also be noted that our early fetal rat lung explants do not demonstrate the accelerated development in organ culture that has been reported with lung tissue from other species, particularly the human $(3,7,9)$. The accelerated maturation in human lung explants raises the possibility that in vivo development may also be regulated by circulating inhibitors from whose influence these explants are released.

In contrast to the findings with the intact explants, studies with enzymatically dissociated monolayer cultures of mixed fetal rabbit (12) and rat (11) lung cells have found that differentiation in culture is dependent on the presence of corticosteroid in the medium. In addition, Torday (27) has reported that in explants of 19-d fetal rabbit lung, maturation in culture was inhibited by the use of charcoal-stripped serum or the addition of $10-\mu \mathrm{M}$ cortexolone to the culture medium. Development was restored by the addition of cortisol to the medium.

To attempt to resolve the issue of whether early fetal rat lung has a requirement for glucocorticoid to begin surfactant synthesis, we have compared the development of cultures grown in medium containing $1 \%$ FCS to that of cultures in which the FCS was charcoal stripped or to which a variety of glucocorticoid antagonists were added. We have shown previously that fetal rat lung explants respond to glucocorticoids by increasing surfactant phospholipid synthesis in a dose-dependent fashion $(15,26)$. Whereas the cultures remained responsive to glucocorticoids and development could be further accelerated by addition of glucocorticoids to the culture medium, no significant delay in macroscopic morphologic maturation or disaturated phosphatidylcholine synthesis was observed in the cultures grown in charcoalstripped serum. Similarly, exposure to a wide range of concentrations of cortexolone, a glucocorticoid antagonist, and 11ketoprogesterone, a blocker of the conversion of inactive dehydrocorticosterone to corticosterone (that has been shown to delay lung maturation in vivo) (28), did not result in a reduction in disaturated phosphatidylcholine synthesis. Clotrimazole, a blocker of glucocorticoid binding in some systems (25), did not antagonize dexamethasone binding in the fetal lungs, nor did it inhibit phosphatidylcholine synthesis.

The most interesting results were those obtained with RU 486. This potent glucocorticoid-binding antagonist has been shown to interact very strongly with the cytoplasmic glucocorticoid receptor in a number of tissues, including rat thymus and a hepatoma cell line $(13,14)$. RU 486 inhibits a number of glucocorticoid-induced effects, including $\mathrm{ACTH}$ release in pituitary cells, uridine incorporation in thymocytes, and tyrosine aminotransferase induction (14), but it has no glucocorticoid agonist activity (13). We have shown that RU 486 is a potent glucocorticoid antagonist in fetal rat lung tissue. It almost completely abolished specific cytoplasmic and nuclear glucocorticoid binding when added to the culture medium in a $3: 1$ ratio with dexamethasone and had no glucocorticoid agonist activity as determined by phosphatidylcholine synthesis, even in concentrations up to $200 \mathrm{nM}$. The concentration of total cortisol in undiluted FCS (Grand Island Biological Co., Grand Island, NY) was found to be $41 \mathrm{nM}$ in a previous study (1). As $1 \% \mathrm{FCS}$ would contain approximately $0.5-\mathrm{nM}$ cortisol, 20 -nM RU 486 should have been more than adequate to completely negate any glucocorticoid effects due to cortisol in the medium or from residual corticosterone present in the lung tissue. [We have previously shown that corticosterone and dexamethasone compete for the same glucocorticoid receptor in fetal rat lung (15), so it can be assumed that RU 486 inhibited corticosterone as well as dexamethasone binding. Corticosterone binds with lower affinity than dexamethasone.] Addition of RU 486 to the culture medium in concentrations varying from $20-200 \mathrm{nM}$ had no obvious effect on macroscopic morphologic development and did not inhibit the development of disaturated phosphatidylcholine synthesis or the appearance of mRNA for SP-A in the cultures. As glucocorticoid stimulation of fetal lung phosphatidylcholine synthesis requires the presence of receptor-bound steroid (37), receptor blockade is a very specific approach to evaluating the role of glucocorticoids.

This study does not exclude the possibility that the subsequent expression of the genes involved in surfactant production is influenced by exposure to glucocorticoids or other hormones early in development. These data do, however, provide strong evidence that the induction of expression of the genes for SP-A and the enzymes regulating surfactant phospholipid synthesis are not dependent on the presence of glucocorticoids. The concentration of other hormones in culture medium with $1 \%$ FCS was extremely low and unlikely to influence lung maturation (free T4, $0.5 \mathrm{pM}$; total T3, $15 \mathrm{pM}$ ) (1). The fact that enzymatically dispersed lung cell cultures appear to be dependent on glucocorticoids for their continuing development $(11,12)$ and the more intact explants do not suggests that endogenous factors such as extracellular matrix components, cell to cell interactions, or growth factors may play a major role in initiating surfactant production. It seems likely that the genes responsible for surfactant production are activated by signals contained within the lung tissue itself and that the role of circulating hormones is later acceleration and modulation of this process.

Acknowledgments. The authors thank Ms. Debra Camputaro for help with the manuscript. RU 486 was a gift of the Centre de Recherche Roussel Uclaf and Dr. Philip Ballard.

\section{REFERENCES}

1. Gross I, Wilson CM 1983 Fetal rat lung maturation: initiation and modulation. J Appl Physiol 55:1725-1732

2. Hummelink R, Ballard PL 1986 Endogenous corticoids and lung development in the fetal rabbit. Endocrinology 118:1622-1629

3. Ballard PL, Hawgood S, Liley H, Wellenstein G, Gonzales LW, Benson B, Cordell B, Tyler White R 1986 Regulation of pulmonary surfactant apoprotein SP 28-36 gene in fetal human lung. Proc Nat Acad Sci USA 83:95279531

4. Funkhouser JD, Hughes ER, Peterson RDA 1976 An organ culture system for study of fetal lung development. Biochem Biophys Res Commun 70:630637

5. Longmuir KJ, Snyder JM, Mendelson CR, Johnston JM 1981 Phospholipid composition of lamellar bodies formed by fetal rabbit lung type II cells in culture. Arch Biochem Biophys 212:491-500

6. Simpson LL, Tanswell AK, Joneja MG 1985 Epithelial cell differentiation in organotypic cultures of fetal rat lung. Am $\mathbf{J}$ Anat 172:31-40

7. Snyder JM, Johnston JM, Mendelson CR 1981 Differentiation of type II cells of human fetal lung in vitro. Cell Tissue Res 220:17-25

8. Weaver TE, Ross G, Daugherty C 1986 Synthesis of surfactant associated protein, 35,000 daltons, in fetal lung. J Appl Physiol 61:694-700

9. Whitsett JA, Pilot T, Clark JC, Weaver TE 1987 Induction of surfactant protein in fetal lung: effects of CAMP and dexamethasone on SAP-35 RNA and synthesis. J Biol Chem 262:5256-5261

10. Gross I, Smith GJW, Maniscalco WM, Czajka MR, Wilson CM, Rooney SA 1978 An organ culture model for the study of the biochemical development of fetal rat lung. J Appl Physiol 45:355-362

11. Tanswell AK, Joneja MG, Lindsay J, Vreeken F 1983 Differentiation-arrested rat fetal lung in primary monolayer cell culture: I: development of a differentiation-arrested and growth-supporting culture system using carbonstripped bovine fetal calf serum. Exp Lung Res 5:37-48

12. Torday JS 1980 Glucocorticoid dependence of fetal lung maturation in vitro. Endocrinology 107:839-844

13. Chobert M, Barouki R, Finidori J, Aggerbeck M, Hanoume J, Philibert D Deraedt R 1983 Antiglucocorticoid properties of RU 38486 in a differentiated hepatoma cell lung. Biochem Pharmacol 32:3481-3483

14. Moguilewsky M, Philibert D 1984 RU 38486: potent antiglucocorticoid activity 
correlated with strong binding to the cytosolic glucocorticoid receptor followed by an impaired activation. J Steroid Biochem 20:271-276

15. Rooney SA, Dynia DW, Smart DA, Chu AJ, Ingleson LD, Wilson CM, and Gross I 1986 Glucocorticoid stimulation of choline-phosphate cytidylyltransferase activity in fetal rat lung: receptor response relationships. Biochim Biophys Acta 888:208-216

16. Sato $G 1974$ The establishment of hormone-dependent cell lines. In: Fleisher $\mathrm{S}$, Packer L (eds) Methods in Enzymology. Academic Press, New York, pp $557-561$

17. Lowry OH, Rosebrough NJ, Farr AL, Randall RJ 1951 Protein measurement with the Folin phenol reagent. J Biol Chem 193:265-275

18. Ballard PL, Ballard RA, Gonzales LK, Wilson CM, Gross I 1984 Corticosteroid binding by fetal rat and rabbit lung in organ culture. J Steroid Biochem 21:117-126

19. Chirgwin JM, Przybyla AE, MacDonald RJ, Rutter WJ 1979 Isolation of biologically active ribonucleic acid from sources enriched in ribonuclease. Biochemistry 18:5294-5299

20. Floros J, Phelps DS, Tauesch HW 1985 Biosynthesis and in vitro translation of the major surfactant-associated protein from human lung. $J$ Biol Chem 260:495-500

21. Floros J, Steinbrink R, Jacobs K, Phelps D, Kritz R, Recny M, Suiltaman L, Jones S 1986 Isolation and characterization of cDNA clones for the $35 \mathrm{kDa}$ pulmonary surfactant-associated protein. J Biol Chem 261:9029-9033

22. Floros J, Phelps DS, Kovrembanas S, Taeusch HW 1986 Primary translation products, biosynthesis, and tissue specificity of the major surfactant protein in rat. J Biol Chem 261:828-831

23. Phelps DS, Taeusch HW, Benson B, Hawgood S 1984 An electrophoretic and immunochemical characterization of human surfactant-associated proteins. Biochim Biophys Acta 791:226-238

24. Sano K, Fisher J, Mason R, Kuroki Y, Schilling J, Benson B, Voelker D 1987 Isolation and sequence of a cDNA clone for the rat pulmonary surfactantassociated protein (PSP-A). Biochem Biophys Res Commun 144:367-374

25. Loose DS, Stover EP, Feldman D 1983 Ketoconazole binds to glucocorticoid receptors and exhibits glucorcorticoid antagonist activity in cultured cells. J
Clin Invest 72:404-408

26. Gross I, Wilson CM, Ingleson LD, Brehier A, Rooney SA 1980 Fetal lung in organ culture: III: comparison of dexamethasone, thyroxine, and methylxanthines. J Appl Physiol 48:872-877

27. Torday JS 1985 Formal demonstration of glucocorticoid-dependent fetal lung SPC synthesis. Pediatr Res 19(suppl):164(abstr)

28. Smith BT 1978 The role of pulmonary corticosteroid 11-reductase activity in lung maturation in the fetal rat. Pediatr Res 12:12-14

29. Ballard PL 1985 Role of endogenous corticosteroids. In: Hormones and Lung Maturation. Springer-Verlag, Berlin pp 94-100

30. Kitterman JA, Liggins GC, Campos GA, Clements JA, Forster CS, Lee CH Creasy RK 1981 Prepartum maturation of the lung in fetal sheep: relation to cortisol. J Appl Physiol 51:384-390

31. Mescher EJ, Platzker ACG, Ballard PL, Kitterman JA, Clements JA, Tooley WH 1975 Ontogeny of tracheal fluid, pulmonary surfactant and plasma corticoids in the fetal lamb. J Appl Physiol 39:1017-1021

32. Martin CE, Cake NH, Hartman PE, Cook IF 1977 Relationship between foetal corticosteroids, maternal progesterone and parturition in the rat. Acta Endocrinol 84:167-176

33. Van Baelen H, Vandoren G, P DeMoor 1977 Concentration of transcortin in the pregnant rat and its foetuses. $J$ Endocrinol 75:427-431

34. Savu L, Junez E, Jayle M 1977 Corticosterone binding by mouse sera during foetal and postnatal development. Acta Endocrinol (Copenh) 84:177-190

35. Liggins GC, Kitterman JA, Campus GA, Clements JA, Forster CS, Lee CC, Creasy RK 1981 Pulmonary maturation in the hypophysectomized ovine fetus: differential responses to adrenocorticotrophin and cortisol. J Dev Physiol 3:1-14

36. Strum JM, Wicken J, Stanbury JR, Karnovsky MJ 1971 Appearance and function of endogenous peroxidase in fetal rat thyroid. $J$ Cell Biol 51:162175

37. Gross I, Ballard PL, Ballard RA, Jones CT, Wilson CM 1983 Corticosteroid stimulation of phosphatidylcholine synthesis in cultured fetal rabbit lung. Evidence for de novo protein synthesis mediated by glucocorticoid receptors. Endocrinology 112:829-837 